Journal of Social Sciences 7 (3): 436-442, 2011

ISSN 1549-3652

(C) 2011 Science Publications

\title{
The Effectiveness of a Training Program Based on Cognitive Research Trust Strategies to Develop Seventh Grade Students' Critical Thinking in History Course
}

\author{
Zaid Suleiman Mohammad Al-Edwan \\ Department of Educational Sciences, Al-Balqa Applied University, Jordan
}

\begin{abstract}
Problem statement: This study focused on the importance of critical thinking in teaching methods especially in history course such as using thinking programs in teaching, this study aimed at exploring the effectiveness of a training program based on Cognitive Research Trust (CoRT) strategies to develop seventh grade student's critical thinking in history course. Approach: To achieve this goal, a training program was designed based on CoRT strategies. A critical thinking test was prepared for the chapter entitled as "The Age of Revolutions". The study sample consisted of 163 seventh grade male and female students in Amman Second directorate. The subjects were divided into two groups. The experimental group consisted of 80 male and female students, who were taught through the CoRT program and the control group which consisted of 83 students who were taught regularly. Results and Conclusion: The results showed that there are statistical differences in seventh grade student's critical thinking for history course related to teaching methodology and for the way of the training program which is based on CoRT strategies.
\end{abstract}

Key words: CoRT strategies, critical thinking, history course, seventh grade students, teaching methods, economy project, training program, research trust strategies, experimental group

\section{INTRODUCTION}

Thinking is a process that accompanies humans permanently. Due to humans' need for it, critical thinking skill became a contemporary issue in education because the individual who has this skill is able to think independently, take right decisions and support the social, political and economic systems in his or her community (Cooper, 2010).

So, Knowledge Economy Project focused on critical thinking as one of the strategies of teaching (Eggen and Kanchak, 2006). Generally, Social Studies curricula and History curriculum, specifically, are considered the fields that focus on critical thinking skills due to the fact that History course help the learner develop his or her critical thinking and solve problems (Zarrillo, 2003).

Consequently, educational institutions took care of enriching textbooks and school curricula with critical thinking skills since this is an important part of the process of education development and as an aim among many of education quality (White, 2000).

The importance of critical thinking is embodied in the individual's ability to judge, understand, apply, evaluate and compare things and study facts and organize and categorize thoughts to get to the accurate and correct solution (Segal et al., 1985). This means that critical thinking consists of many skills: inference, recognition of assumptions, deduction, interpretation and evaluation of arguments (Lefrancois, 2005).

These skills need a thinking development program (Bono, 1994). And, CoRT program is considered the most frequently used program all over the world in the contemporary time and it consists of six units: breadth, organization, interaction, creativity, information and feeling and action (Debono, 1986).

History course is taken as one of the courses that contribute in shaping the individual personality and helps in research, correct planning, criticizing, deducing, comparing and getting the lessons (Paul, 1993). Also, the study of history gives the individual the chance to acquire thinking skills, specifically, critical thinking skill (Bono, 1987).

Paul emphasizes that citizenship is embodied in the citizen who has critical thinking skill especially in the age of globalization and technological advancement in which information resources are varied and this gave the importance of relating CoRT program with developing critical thinking skills (Tripp, 1980). 


\section{J. Social Sci., 7 (3): 436-442, 2011}

As a result, the Ministry of Education took care of renewing and developing teaching methodologies and critical thinking skills were inserted in teaching methods aiming at achieving the complete growth for learners and to have the good citizen in the different aspects of personality and it took the requirements of our time into consideration (Paul, 1993).

History course aims are embodied in having the good citizen who is aware to his or her community problems and who is able to solve them reasonably and it also aims at providing the students with information, values, attitudes and skills they apply in their life which make them able to solve their problems in a correct and scientific way and it also aims at developing their critical thinking skills (Lohman and Woolf, 2001).

Nevertheless, some studies, such as (Huppert et al., 1998) showed some difficulties that students face during learning History as the teaching methods used in the past may not be harmonious with the information community, so we should work to be able to deal with the changes and revise the strategies so as the students will acquire information and skills which their prospective roles require in the light of information community (Tripp, 1980). Traditional methods became insufficient to cause the hoped changes and shape the learner's comprehensive personality which is able to deal with development and modernism, while the modern educational methods started focusing on using thinking programs.

Teaching thinking at schools got to be a necessity due to what students face daily such as situations and issues that teachers think about, students also face varied situations outside schools where critical thinking is important for achieving success. If teachers do not move to teach students critical thinking strategies, success opportunities in life aspects will become so limited (Debono, 1986).

One can say that achieving History course aims, specifically, does not occur unless we focus on the high mental processes such as critical thinking skills which need programs and strategies to motivate students' creativity. As a result, this study is meant to explore the effectiveness of a training program based on CoRT strategies to develop critical thinking in the History course for elementary seventh grade students (Lohman and Woolf, 2001).

Ruland conducted a study which aimed at testing the relationship between the features of classroom and educational environment (surveying, argument, discussion and cooperative learning ways) in developing critical thinking skills. The findings of the study showed that the class environment features are considered one of the strong indicators of critical thinking growth especially argument and discussion (Huppert et al., 1998).

To the best of the researcher's knowledge, there are no more studies that talked the effect of using CoRT program for teaching History on the development of the shill of critical thinking so The present study made use of the methodology used in some of the previous studies, but it is distinguished from them in designing a program based on CoRT strategies in History course by the researcher.

Study problem: The study problem results from the necessity of varying the used teaching methods in teaching History course such as using thinking programs in teaching it because many previous studies indicated the students' dislike of social studies topics such as Jarwan study. Specifically, the nature of the topics of History course are affected by the two-dimension problem; place and time and contain abstract concepts some of which are out of the learner's environment. So, teaching it in various ways might contribute to solving those problems and get the information closer to the student's mind. And, some people look at History course as a rigid course which depends on knowing by heart and dictation of many historical events and issues that occurred during the past ages, that it is limited to provide students with information only without taking into consideration developing students thinking abilities such as critical thinking.

Due to the importance of thinking for the community and individual, the demand of the necessity to include critical thinking skills in school curricula increased specifically History curricula as they are important in making students acquire the mental skills such as analysis, elicitation, interpretation and problem solving in a more effective way. Particularly, students , in our contemporary technology age, face many life and classroom situations that need thinking to solve and know what the situation include exactly and this requires focusing hugely on developing critical thinking skills. Consequently, this study came to explore the effectiveness of a training program based on CoRT strategies for developing critical thinking in History course for elementary seventh grade students.

Objectives: This study aims at exploring the effectiveness of a training program based on CoRT strategies to develop critical thinking in History course for elementary seventh grade students.

Study importance: The study importance results from many things. First, it results from the importance of CoRT program and what it includes as skills and 


\section{J. Social Sci., 7 (3): 436-442, 2011}

strategies, which will be used in the present study. It also results from the importance of History course in developing good citizenship, shaping the students' personality and behavior and reserving the values of the community, so teaching it in modern and cooperative ways including CoRT program is an important issue to achieve its aims and comprehending its concepts.

Additionally, the importance of this study is clear in designing a training program based on CoRT program strategies in History course by the researcher that might contribute to achieving the aims of teaching it which is based on knowledge economy and which takes critical thinking as one of its strategies. So, this study might be considered as a feedback for the Ministry of Education. The findings of the study might have an active effect to draw the attention of those who work on the educational process to make use of CoRT program and use it in teaching History course and provide researchers and social studies curricula planners with an experience regarding using the program in teaching History course.

Moreover, the study importance derives from its modernity and originality since the Arab and Jordanian environment lacks-to the best of the researcher's knowledge- studies that tackled the problem and variables of the present study.

The study question: Are there statistical differences at the level of significance $(\alpha \leq 0.05)$ in elementary seventh grade student's critical thinking in History course which are related to variables such as: teaching methods, gender and the interaction between both of them?

\section{Procedural definitions:}

- The standard method: It is a method of teaching that is based on that the teacher adopts the principle of dictation and discussion in conveying information for students and relying on the textbook and using the same procedures with all students. This is the prominent method of teaching History course in most of our schools

- Critical thinking: It is the total score that students got in Watson and Glesar's test for critical thinking. This test includes the following skills: assumptions recognition, interpretation, deduction, elicitation and evaluation of argument

- The training program which is based on CoRT strategies: It is a group of activities which included different situations prepared by the researcher and distributed over 20 periods. This program consists of the unit which is entitled age of revolution the elementary seventh grade History course. This program has two parts: breadth and organization

- Breadth: It is the first part of CoRT program for developing thinking and which consists of ten lessons, one period for each lesson, which are: Plus-minus-Interest, consider all rules, rules, consequence and squat, objectives, goals and aims, planning, first important priorities, alternatives and possibilities, decision and other people views

- Organization: It is the second part of CoRT program for developing thinking and which consists of ten lessons, one period for each lesson. It defines: Recognize, analyze, compare, select, find another way, start, organize, focus, consolidate and conclude

Study limitation: This study is limited to a group of elementary seventh grade students of Amman Second Directorate who are enrolled in governmental schools for the academic year 2009/2010. It is also limited to teaching the unit which is entitled "The Age of Revolutions" in the elementary seventh grade History textbook. A point to add is that the study has special features for it psychometric tools used in it.

\section{MATERIALS AND METHODS}

\section{Methodology and procedures: \\ Study approach:}

The study followed the empirical approach: Sample: The sample of study contained 163 elementary seventh male and female students -82 males and 81 females-who are enrolled in Amman Second Directorate governmental schools for the academic year 2009/2010. The two schools were chosen in the simple random method.

The researcher chose two schools. One of them is for boys which is Sweleh Secondary School for Boys in which the seventh grade is two classes from which were one chosen by lot to be the experimental group and the other to be the control one. Class (A) represented the experimental group which had 42 students and class (B) represented the control group which had 40 students.

The other school was for girls which is Sweleh Secondary School for Girls in which the seventh grade is three classes. Class (C) represented the control group which had 43 students and class (B) represented the experimental group which had 38 


\section{J. Social Sci., 7 (3): 436-442, 2011}

students. It seems important to mention that these classes were distributed by lot.

\section{Tools:}

The training program which is based on CoRT strategies: The researcher designed a training program based on CoRT strategies. The educational material consisted of the unit entitled "Ages of Revolutions" in History textbook for elementary seventh grade students in the second term for the academic year 2009/2010. After finishing the preparations of this training program, it was referred to 14 specialized referees in the field of social studies curricula and their teaching methodology. In the light of the referee's suggestions, the researcher did some suitable amendments that $80 \%$ of the referees agreed upon.

The researcher tried the training program on the piloting sample which consisted of 39 students before conducting the experiment on the present study subjects. After doing the amendments suggested by the referees, the researcher taught the experimental group using the training program and the control group using a standard method. The application of this study consumed 20 periods for each group. At the end of the experiment, a critical thinking post-exam, which contained the same item of the critical thinking pre-exam - was conducted for both groups.

Critical thinking test: The researcher prepared a critical thinking test consisting of 75 true or false items. It was made sure about the truth of these items by showing them to 14 specialized referees in the field of Social Studies curricula and their teaching methods and measurement and evaluation at The University of Jordan, Al-Balqa' Applied University and History teachers.

In the light of the referees' opinions, some of the items were changed which $80 \%$ of the referees agreed upon. The test was checked by applying it on the piloting sample which consisted of 39 male and female students and by calculating the rate of internal consistency by using of Cooder-Richardson's equation (20) which is (0.87).

\section{Procedures:}

- $\quad$ Preparing the study tools (CoRT program and the test of critical thinking)

- Referring the study tools to the referees to make sure of their viability and truth

- Applying and implementing the study tools on the piloting for the calculation of stability

- Conducting the pre-test of critical thinking on the subjects of the study

- Conducting the study by the researcher. That is the experimental group were taught through CoRT program and the controlling one was taught through a usual method
- Conducting the post-test of critical thinking on the subjects of the study

- Doing the statistical analysis and discussing the results

Variables: The independent variables:

- Teaching methods which are two: Learning through using the training program which is based on CoRT program and the standard method of teaching

- Gender: Male and female

The dependent variables: The total score of critical thinking test in History course.

Statistical processing: Having entered data, averages and standards deviations were calculated. Also, ANCOVA (Analysis of Bilateral Covariance) was used so as to control the effect of the differences between the two groups on the pre-test.

\section{RESULTS}

Regarding the question that if is there are statistical differences at the indication rate $(\alpha \leq 0.05)$ in the critical thinking for the elementary seventh grade students in History course related to the variables of teaching methods and gender and the interaction between them, to answer this question, averages and standards deviations were calculated for the two groups' performance in the pre-test and post-test of critical thinking according It is clear in Table 1 that there is a difference between the averages of the critical thinking test in all fields and its pre-test and the post-test

And, to see if these differences of the averages are of statistical significance at the level of $(\alpha \leq 0.05)$, data of the post-test of critical thinking were analyzed via ANCOVA so as to control the effect of the differences between the two groups on the pre-test. Table 2 shows the results of this analysis.

ANCOVA results show that there are statistical differences at the level of significance $(\alpha \leq 0.05)$ in the critical thinking regarding the total grade of the seventh grade students in History course between the two groups; the control and the experimental ones. The statistical value (f) is (4.09) which is the a statistically indicative value at the level of significance $(\alpha=0,04)$. This means that there is an effect of the teaching method on thinking development between the control group which was taught by a standard method and the experimental group that was taught by the training program based on CoRT strategies and for the trial group. 


\section{J. Social Sci., 7 (3): 436-442, 2011}

Table 1: Averages and standard deviations of the pre and post test of critical thinking

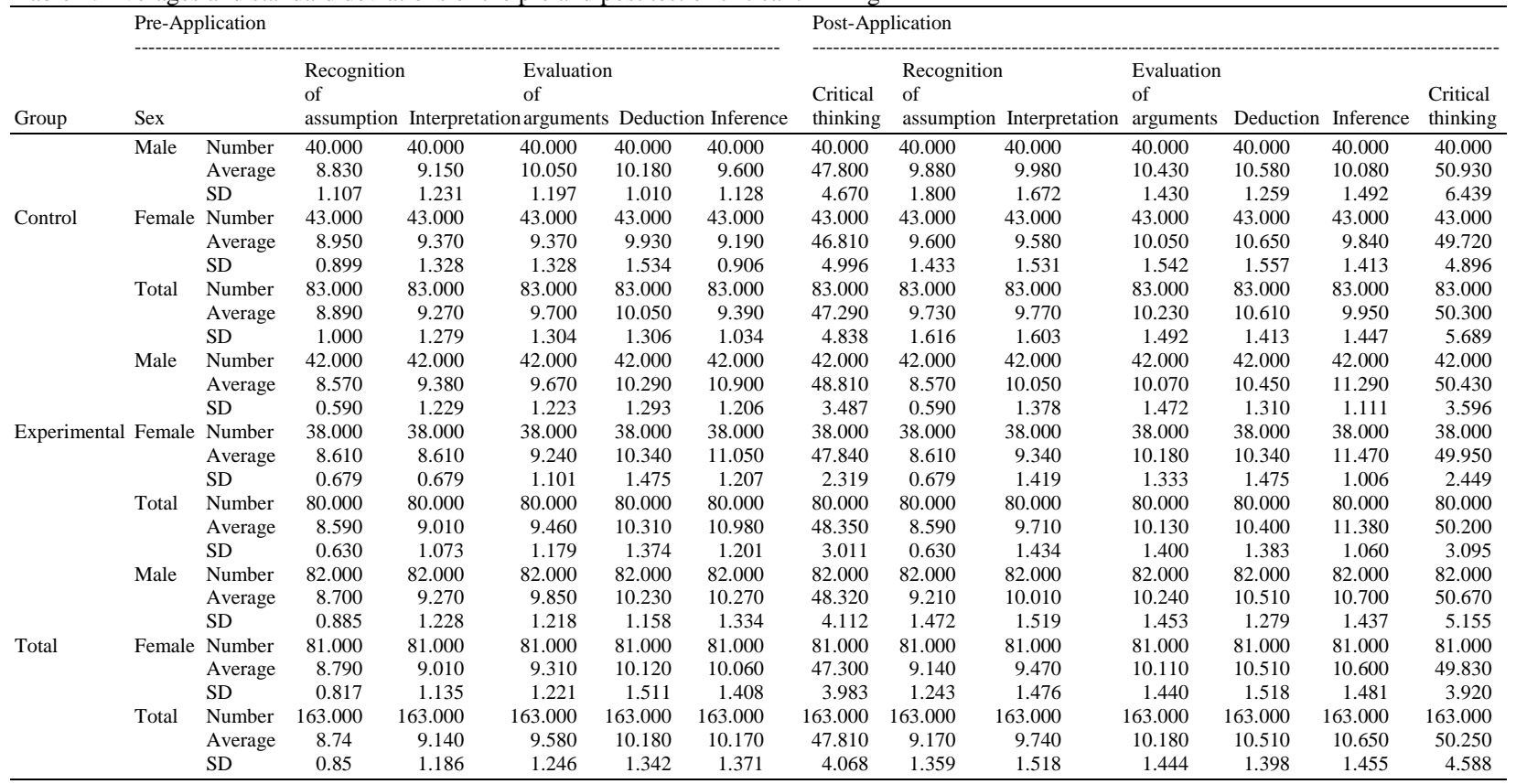

Table 2: Results of analysis of the bilateral covariance (ANCOVA), to test of critical thinking and its fields according to the method of

\begin{tabular}{|c|c|c|c|c|c|c|}
\hline & $\begin{array}{l}\text { Source of variation } \\
\text { significance }\end{array}$ & Sum of squares & $\begin{array}{l}\text { Degree of } \\
\text { freedom }\end{array}$ & $\begin{array}{l}\text { Average of } \\
\text { squares }\end{array}$ & Calculated & $\begin{array}{l}\text { Statistical } \\
\text { value of (f) }\end{array}$ \\
\hline \multirow[t]{6}{*}{ Critical thinking } & (With) Critical thinking & 1847.655493 & 1 & 1847.65549000 & 191.0600 & $* 0.000$ \\
\hline & Teaching method & 39.5655539 & 1 & 39.56555390 & 4.0913 & $0.040^{*}$ \\
\hline & Gender & 0.013999161 & 1 & 0.01399916 & 0.0014 & 0.970 \\
\hline & Group*gender & 5.082929636 & 1 & 5.08292964 & 0.5256 & 0.470 \\
\hline & Error & 1527.951121 & 158 & 9.67057672 & & \\
\hline & Total & 415021 & 163 & & & \\
\hline \multirow[t]{6}{*}{ Recognition of assumption } & $\begin{array}{l}\text { (With) recognition of } \\
\text { Assumption }\end{array}$ & 68.035 & 1 & 68.03500000 & 61.0820 & $* 0.000$ \\
\hline & Group & 33.187 & 1 & 33.18700000 & 29.7950 & $* 0.000$ \\
\hline & Gender & 1.332 & 1 & 1.33200000 & 1.1960 & 0.276 \\
\hline & Group*gender & 1.448 & 1 & 1.44800000 & 1.3000 & 0.256 \\
\hline & Error & 175.984 & 158 & 1.11400000 & & \\
\hline & Total & $14,011.00$ & 163 & & & \\
\hline \multirow[t]{6}{*}{ Interpretation } & (With)interpretation & 95.346 & 1 & 95.34600000 & 56.9440 & $* 0.000$ \\
\hline & Group & 0.372 & 1 & 0.37200000 & 0.2220 & 0.638 \\
\hline & Gender & 5.309 & 1 & 5.30900000 & 3.1710 & 0.077 \\
\hline & Group*gender & 1.237 & 1 & 1.23700000 & 0.7390 & 0.391 \\
\hline & Error & 264.551 & 158 & 1.67400000 & & \\
\hline & Total & $15,844.00$ & 163 & & & \\
\hline \multirow[t]{6}{*}{ Evaluation of arguments } & $\begin{array}{l}\text { (With) recognition of } \\
\text { Arguments }\end{array}$ & 102.721 & 1 & 102.72100000 & 70.1210 & $* 0.000$ \\
\hline & Group & 0.16 & 1 & 0.16000000 & 0.1090 & 0.742 \\
\hline & Gender & 2.087 & 1 & 2.08700000 & 1.4240 & 0.234 \\
\hline & Group*gender & 1.088 & 1 & 1.08800000 & 0.7430 & 0.390 \\
\hline & Error & 231.457 & 158 & 1.46500000 & & \\
\hline & Total & $17,223.00$ & 163 & & & \\
\hline \multirow[t]{6}{*}{ Deduction } & (With) deduction & 169.85 & 1 & 169.85000000 & 185.5270 & $* 0.000$ \\
\hline & Group & 6.989 & 1 & 6.98900000 & 7.6340 & $* 0.000$ \\
\hline & Gender & 0.124 & 1 & 0.12400000 & 0.1360 & 0.713 \\
\hline & Group*gender & 1.769 & 1 & 1.76900000 & 1.9320 & 0.166 \\
\hline & Error & 144.649 & 158 & 0.91600000 & & \\
\hline & Total & $18,319.00$ & 163 & & & \\
\hline \multirow[t]{6}{*}{ Inference } & (With) inference & 52.334 & 1 & 52.33400000 & 40.0720 & $* 0.000$ \\
\hline & Group & 9.893 & 1 & 9.89300000 & 7.5750 & $* 0.007$ \\
\hline & Gender & 0.077 & 1 & 0.07700000 & 0.0590 & 0.809 \\
\hline & Group*gender & 0.187 & 1 & 0.18700000 & 0.1430 & 0.706 \\
\hline & Error & 206.347 & 158 & 1.30600000 & & \\
\hline & Total & $18,832.00$ & 163 & & & \\
\hline
\end{tabular}




\section{J. Social Sci., 7 (3): 436-442, 2011}

As it is shown in Table 2, there are statistically indicative differences at the level of significance $(\alpha \leq 0.05)$ in critical thinking skills which are embodied in assumption recognition skill as (f) value is (29.79) which is of statistical indication at the level $(\alpha=0,00)$, deduction skill as (f) value is $(7,63)$ which is of statistical indication at the level $(\alpha=0,006)$, elicitation kill as (f) value is $(7,57)$ which is of statistical indication at the level $(0,007)$. While, the results in Table 2 indicated that there are no statistically indicative differences at the level $(\alpha \leq 0.05)$ in the two critical thinking skills: Interpretation and Evaluation of Argument.

Table 2 also shows that having no statistically indicative differences at the rate $(\alpha \leq 0.05)$ on the total score of critical thinking and for all sub-fields is related to and resulted from sex variable as the (f) value which is calculated is $(0,0014)$ and this value is not indicative statistically at the rate $(\alpha \leq 0.05)$

Table 2 also shows that having no statistically indicative differences at the rate $(\alpha \leq 0.05)$ on the total score of critical thinking and all sub-fields in History course is related to the interaction between the method of teaching and sex as the calculated value of (f) is $(0,526)$ which is not indicative at the level $(\alpha \leq 0.05)$.

\section{DISCUSSION}

It seems to the researcher that the reasons of these results are:

- The accurate organization of presenting the training program might have contributed in spreading factors of suspense and draw the attention of students. The researcher noticed that during the application of the study that students showed positive reactions

- History course-specially the selected unit-contains lots of difficult concepts that need to be facilitated for students to comprehend. CoRT program might have contributed to a huge extent in clarifying these concepts and this issue might develop critical thinking skills for students

- CoRT program includes many activities which resulted in having fun, excitement and curiosity for students. The researcher's notes during the application supports this hypothesis as students showed noticeably active interaction with these activities which was reflected positively on their critical thinking. And, the researcher refers this to planning the lessons according to a CoRT based program with more focus on critical thinking skills and applying it inside classroom with more focus on the teaching method that encourages critical thinking as a method of researching and problem solving. This encourages to move students' thinking towards the high thinking skills

- The researcher might relate these results to the same time and place circumstances for both genders and the educational environment for both males and females are similar i.e., financial facilitation, activities, educational means which are available in the training program are the same for both sexes

- The physical and psychological reinforcing stimuli that students receive are similar regardless of their gender. All of these factors did not show differences between the genders

- The present study findings agree with Al-Beshwai study that indicted and showed the outperformance of the way of learning using CoRT program in developing critical thinking skills for the students comparing it with the standard method

\section{CONCLUSION}

In the light of the findings of the study, there are many recommendations:

- Extending the use of CoRT program for its positive effect on students' achievements and their attitudes towards History course and developing their thinking skills in general and critical thinking skills in particular.

- Draw the attention of educational institution to the necessity of making use of CoRT program in developing critical thinking of Social Studies course students in general and History course students in particular

- The application of CoRT program on the branches of Social Studies such as Geography, National and Civil Education, as the study confirmed the program effect in developing critical thinking

- Conducting a similar study exploring the effect of the remaining parts of CoRT program on developing critical thinking skills. The study confirmed the effect of the program on critical thinking skills development

- Drawing the attention of curricula designers to CoRT program for teaching thinking which might be benefited from in building and planning curricula

\section{REFERENCES}

Bono, E.D., 1987. Cort Thinking Program, Teacher's Notes: Cort 2 - Organization (Cort Thinking Program; Cort 2). 2nd Edn., Pergamon Pres, ISBN13: 978-0080344478, pp: 72. 
Bono, E.D., 1994. De Bono's Thinking Course. 1st Edn., Facts on File, ISBN-10: 0816031789, pp: 1994.

Cooper, J.M., 2010. Classroom Teaching Skills. 9th Edn., Wadsworth Publishing, ISBN-10: 0495812439, pp: 416.

Debono, E., 1986. Edward De Bono's Cort Thinking Teacher's Notes: Book 4: Creativity. 2nd Edn., Pergamon Press, ISBN-10: 0080344518, pp: 64.

Eggen, P.D. and D.P. Kanchak, 2006. Educational Psychology: Windows on Classrooms. 7th Edn., Prentice Hall, ISBN: 0132227428, pp: 672.

Huppert, J., J. Yaakobi and R. Lezarovvitz, 1998. Learning microbiology with computer simulations: Students' academic achievement by method and gender. Res. Sci. Technol. Educ., 16: 231-245. DOI: 10.1080/0263514980160210.

Lefrancois, G.R., 2005. Theories of Human Learning: What the Old Woman Said. 5th Edn., Wadsworth Publishing, ISBN-10: 0534641520, pp: 496.

Lohman, M.C. and N.H. Woolf, 2001. Self-initiated learning activities of experienced public school teachers: methods, sources, and relevant organizational influences. Teach. Teach., 34: 5974. DOI: $10.1080 / 13540600123835$
Paul, R., 1993. Critical thinking: What every person needs to survive in a rapidly changing world. $3^{\text {rd }}$ Edn., Foundation for Critical Thinking, Santa Rosa ISBN: 0944583083, pp: 505.

Segal, J.W., S.F. Chipman and R. Glaser, 1985. Thinking and Learning Skills: Volume 1: Relating Instruction to Research (Psychology of Education and Instruction Series). 2nd Edn., Routledge, ISBN-10: 0898591651, pp: 554.

Tripp, D.H., 1980. The evaluation of the De Bono (CoRT*) thinking project: Some theoretical issues. Stud. Educ. Evaluat., 6: 185-194.

White, C., 2000. Issues in Social Studies: Voices from the Classroom. 1st Edn., Charles C. Thomas Publisher, USA., ISBN-13: 978-0398070588, pp: 207.

Zarrillo, J., 2003. Teaching Elementary Social Studies: Principles and Applications. 2nd Edn., Prentice Hall, New Jersey, ISBN-10: 0131128442, pp: 416. 